\title{
Study of Hydraulic Jump Length Coefficient with the Leap Generation by Canal Gate Model
}

\author{
Bambang Sulistiono, Lalu Makrup \\ Department of Civil Engineering, Islamic University of Indonesia, Yogyakarta, Indonesia
}

Email address:

885110106@uii.ac.id (L. Makrup), lalu_makruf@yahoo.com (L. Makrup)

\section{To cite this article:}

Bambang Sulistiono, Lalu Makrup. Study of Hydraulic Jump Length Coefficient with the Leap Generation by Canal Gate Model. American Journal of Civil Engineering. Vol. 5, No. 3, 2017, pp. 148-154. doi: 10.11648/j.ajce.20170503.14

Received: February 22, 2017; Accepted: March 20, 2017; Published: April 7, 2017

\begin{abstract}
The length of hydraulic jump is a parameter needed to design the stilling basin dimension in the downstream of the weir or the other water structure in the river and channel. To determine the hydraulic jump length was needed function with some flow variables associated with the hydraulic jump phenomenon. One of variable to obtain the hydraulic jump was the hydraulic jump length coefficient $\left(C_{\mathrm{j}}\right)$. A study to determine the hydraulic jump length coefficient was conducted experimentally in laboratory. The data of experiment result was analyzed by regression technic. The results are the hydraulic jump length coefficient in fixed value and function with variable is a ratio of upstream and downstream depth of the the hydraulic jump.
\end{abstract}

Keywords: Flow, Depth, Coefficient, Hydraulic Jump Length

\section{Introduction}

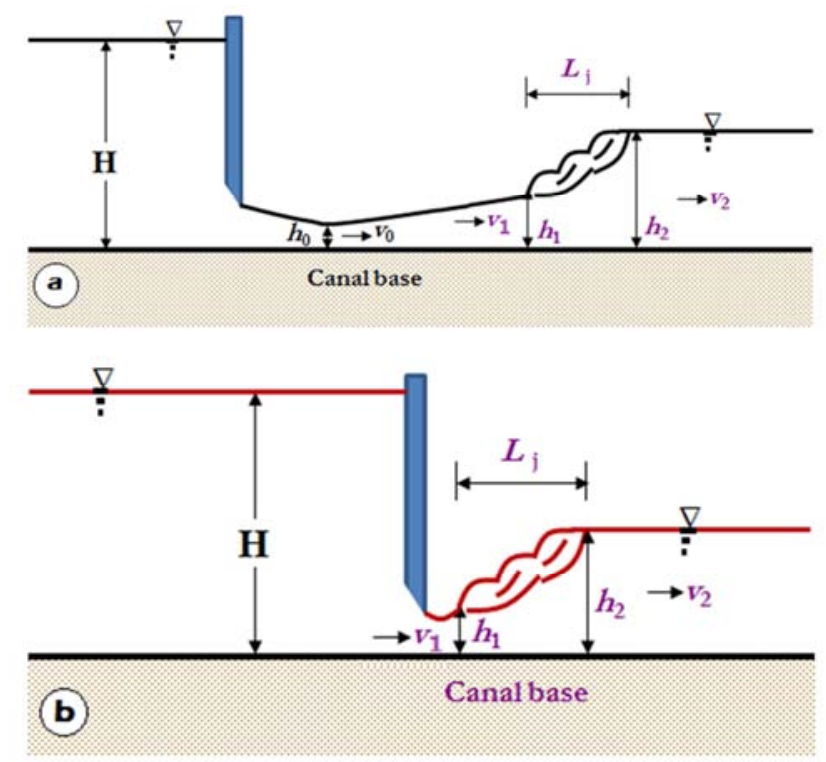

Figure 1. Flow pattern in upstream and downstream of the canal gate.

In the case of the waterworks structure construction in the river or canal, so the waterworks will cause the flow pattern in the canal will change. As an example if in the canal has been built a weir or canal gate for irrigation purpose (Figure 1), then in upstream and the downstream of the structure the flow parameters will be change. In the upstream exist the slow flow (the flow velocity will be decrease and the flow depth will be increase). In the downstream of the gate the flow velocity will be increase, the flow depth will be decrease, and the flow pattern to be complicated. Occasionally the hydraulic jump generated in downstream of the gate on flow pattern as Figure $1 \mathrm{a}$ or $1 \mathrm{~b}$.

The sketch of the flow pattern in upstream and downstream of the canal gate can be seen in Figure 1a and $1 \mathrm{~b}$.

The flow pattern in the downstream of the canal gate Figure 1a, imply that will be occurred flow with high velocity along hydraulic jump running with the length $L_{0}$ and the circular flow on along hydraulic jump with length $L_{\mathrm{j}}$. The condition can scour the canal base along $L_{0}+L_{\mathrm{j}}$, if the place is not protected. The flow pattern in form of the hydraulic jump in the downstream of the canal gate Figure $1 \mathrm{~b}$ shows that scouring will be occurred along the hydraulic jump only. So that the canal base that need protection is along the hydraulic jump solely. The two conditions of the downstream gate flow pattern indicate that the hydraulic jump should be brought closer to the foot gate by hydraulics analysis (Figure 1b) so 
as the protection of the canal base can be shorter and the cost of canal protection will be cheaper.

Study of hydraulic jump or hydraulic jump length $\left(L_{\mathrm{j}}\right)$ as in Figure 1 was conducted by many experts in hydraulic engineering.

a. A ccording to hydraulic jump phenomenon some researchers have given the results of their study. $i$ ) Chanson and Montes (1995) perform experimental research of undular hydraulic jump in a rectangular channel. Visual and photographic observations result indicated five types of undular jumps. One of the main flow characteristics is the presence of lateral shock waves for Froude numbers larger than 1.2. The other results show that the disappearance of undular jump occurs for Froude numbers ranging from 1.5 to 2.9 and that the wave length and amplitude of the free-surface undulations are functions of the upstream Froude number and the aspect ratio of critical flow depth and width of channel. ii) Chanson (1996) studied hydraulic jump which was characterized by free-surface undulations that develop downstream of the jump for low upstream Froud numbers. Experimental study was performed in rectangular cross section flume with fullydeveloped upstream flows. The result show a major three-dimentional flow redistributions immediatly upstream of the wave crest. Velocity and pressure distributins were recorded at very close intervals in that region. They provide some understanding of the flow redistribution mechanisms. A dominant features of the undular jump flow is the presence of lateral shockwave superposed over the free-surface undulations. iii) Alikhani et al. (2010) performed experimental study to evaluate effects of a single vertical continous sill and its position on control of depth and length of a forced jump in stilling basin without considering tailwater depth which is variable and totally controlled by downstream river conditions. The hydraulic characteristics of the jump were measured and compared with the classical hydraulic jump under variable discharges. Results of experiments confirmed significant effect of the sill on dissipation of energy. A new relationship was developed between sill height and position, sequent depth ratio, and length of stilling basin. The advantage of the proposed relationship in practice is its capability to design stilling basin where tail water depth is unpredictable.

b. According to hydraulic jump length equations some researchers have given the results as follow. Ludin (1927), Safranez (1933-39), Douma (1934), Chertoussov (1935), Page (1935), and Posey (1941) gave the hydraulic jump length $\left(L_{\mathrm{j}}\right)$ as equation (1), (2), (3), (4), (5), and (6) respectively.

$$
\begin{gathered}
L_{\mathrm{j}}=h_{2}\left(4.5-V_{1} / V_{\mathrm{c}}\right) \\
L_{\mathrm{j}}=5.2 h_{2} \\
L_{\mathrm{j}}=3.0 h_{2}
\end{gathered}
$$

$$
\begin{aligned}
& L_{\mathrm{j}}=10.3 h_{1}\left(\mathrm{~F}_{\mathrm{r} 1}-1\right)^{0.81} \\
& L_{\mathrm{j}}=10.3 h_{1}\left(\mathrm{~F}_{\mathrm{r} 1}-1\right)^{0.81} \\
& L_{\mathrm{j}}=4.5-7\left(h_{2}-h_{1}\right)
\end{aligned}
$$

a. According to hydraulic jump length coefficient $(\mathrm{Cj})$ as in equation (7) some researchers have given coefficient values as follow.

$$
L_{\mathrm{j}}=C_{\mathrm{j}}\left(h_{2}-h_{1}\right)
$$

Bakhmeteff, Matzke (1936), Smetana, Kinney (1935), Riegel and Beeba (1917), Aravin (1935) gave the value of the hydraulic jump length coefficient, $C_{\mathrm{j}}=5,6,6.2,5$, and 5.4 respectively. Triatmojo (1993) gave $C_{\mathrm{j}}=5$ to 7 .

b. The coefficient $(\mathrm{Cj})$ in a function form associated with equation (7) some researchers have given functions as follow.

c. Wu (1949), Woycicki (1931), and Ivanchenko (1935) gave the functions to compute $\mathrm{Cj}$ in Equations (8), (9), and (10) respectively.

$$
\begin{aligned}
& C_{\mathrm{j}}=10 F r_{1}{ }^{-0.16} \\
& C_{\mathrm{j}}=8-0.05 h_{2} / h_{1} \\
& C_{\mathrm{j}}=10.6\left(\mathrm{Fr}_{1}{ }^{2}\right)^{-0.185}
\end{aligned}
$$

In this paper the equation of hydraulic jump length coefficient was developed associated with Figure 2, equation (7), and (9).

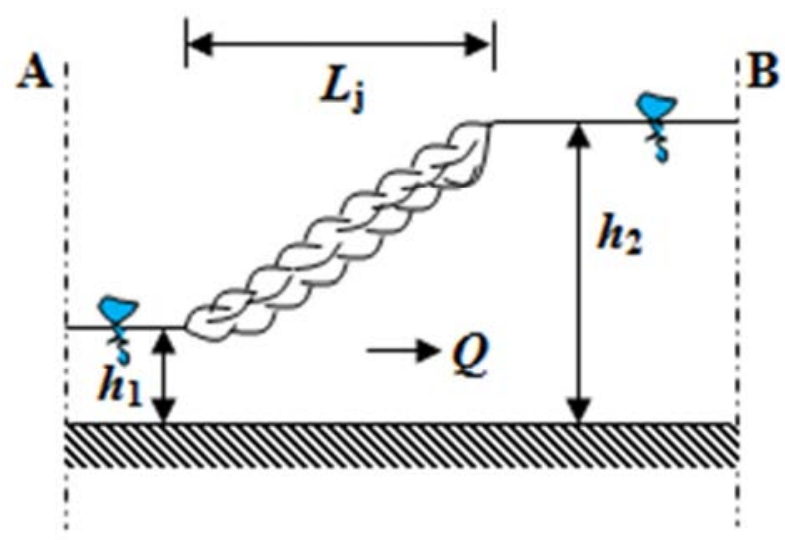

Figure 2. Hydraulic jump.

Where,

$L_{\mathrm{j}}=$ length of hydraulic jump

$C_{\mathrm{j}}=$ hydraulic jump length coefficient

$h_{1}=$ water depth in section A

$h_{2}=$ water depth in section B

$Q=$ discharge of the flow

The equations of hydraulic jump length coefficient which desired are such as in Equation (11)

$$
C_{\mathrm{j}}=a+b h_{1} / h_{2}
$$

And

$$
C_{\mathrm{j}}=a+b\left(h_{1} / h_{2}\right)^{\mathrm{s}}
$$


Where $a$ and $b$ are parameters that can be determined based on data measurement result and regression analysis and $\mathrm{s}$ is determined as a fixed value associated with optimum correlation coefficient from regession analysis. The variable $h_{1} / h_{2}$ is the ratio of water depth in critical flow condition in upstream of hydraulic jump and water depth in subcritical flow condition in downstream of hydraulic jump, different from variable which has been used by Woycicki (1931) Equation (9) i.e. ratio of $h_{2} / h_{1}$.

\section{Hydraulic Jump Equation}

Hydraulic jump can be occurred if the flow in the canal changed from the supercritical flow to the subcritical flow (Figure 2). Hydraulic jump equation was derived by experts with flow type was steady flow or rapid varied flow as in Figure 3.

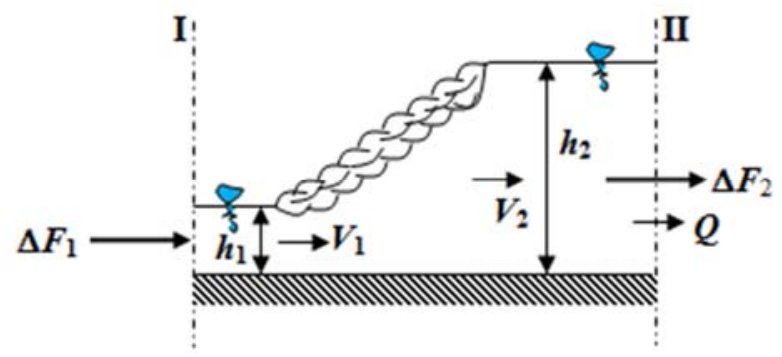

Figure 3. Rapid varied flow.

From Figure 3 can be found that the pressure force $\left(F_{\mathrm{p}}\right)$ between section I and II is,

$$
F_{\mathrm{p}}=1 / 2 \rho g\left(h_{2}^{2}-h_{1}^{2}\right) b
$$

And the velocity force $\left(F_{\mathrm{v}}\right)$ between section I and II is,

$$
F_{\mathrm{v}}=\rho Q\left(V_{1}-V_{2}\right)
$$

For the along rapid varied flow Figure 3 the two forces is balance so,

$$
1 / 2 \rho g\left(h_{2}^{2}-h_{1}^{2}\right) b=\rho Q\left(V_{1}-V_{2}\right)
$$

Where the section I is the supercritical flow and section II is subcritical flow, and,

$\rho=$ mass density of water

$g=$ gravity acceleration

$V_{1}=$ flow velocity in section I

$V_{2}=$ flow velocity in section II

$b=$ width of the rectangular canal

Equation (14) can be rearrange to find the hydraulic jump equation to determine downstream depth of hydraulic jump, Equation (15) and (16).

$$
\frac{h_{2}}{h_{1}}=1 / 2\left(\sqrt{1+\frac{8 q^{2}}{g h_{1}^{3}}}-1\right)
$$

Or

$$
\frac{h_{2}}{h_{1}}=1 / 2\left(\sqrt{1+8 F_{r 1}^{2}}-1\right)
$$

\section{Methods}

Experiments were performed in a 10-m long channel of uniform rectangular section made of glass (bottom and sidewalls), located in the Hydraulic Laboratory of the Islamic University of Indonesia (Figure 4). The channel width is 0.10 $\mathrm{m}$ and the sidewall height is approximately $0.40 \mathrm{~m}$. The channel is supported on an elevated steel frame which spans between main supports. The channel slope can be adjusted using a geared lifting mechanism but for the study was done in horizontal channel condition. Tail water levels are controlled by a radial gate fitted at the downstream channel end.

The water discharge was measured typically using a bend, installed in below of the end of the channel flume (Figure 5). The two quantitative measured discharges were gauged by the bend i.e. 1.072 liter/second and 1.387 liter/second. The two discharges were used in this study.

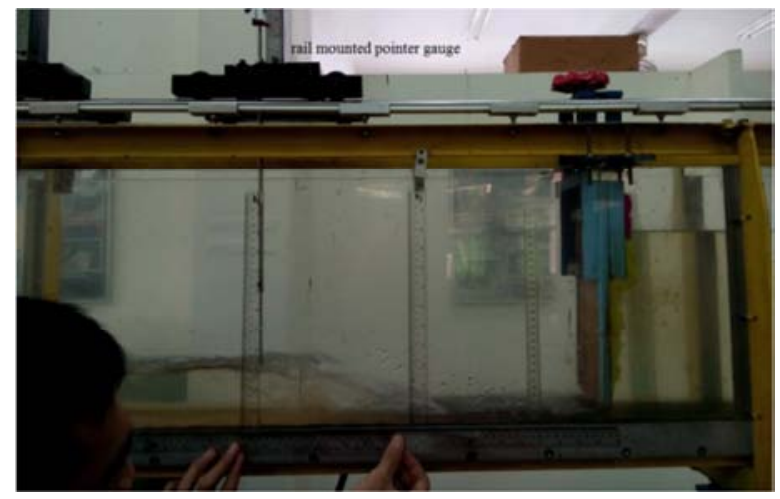

Figure 4. Channel flume in hydraulic laboratory of Islamic University of Indonesia.

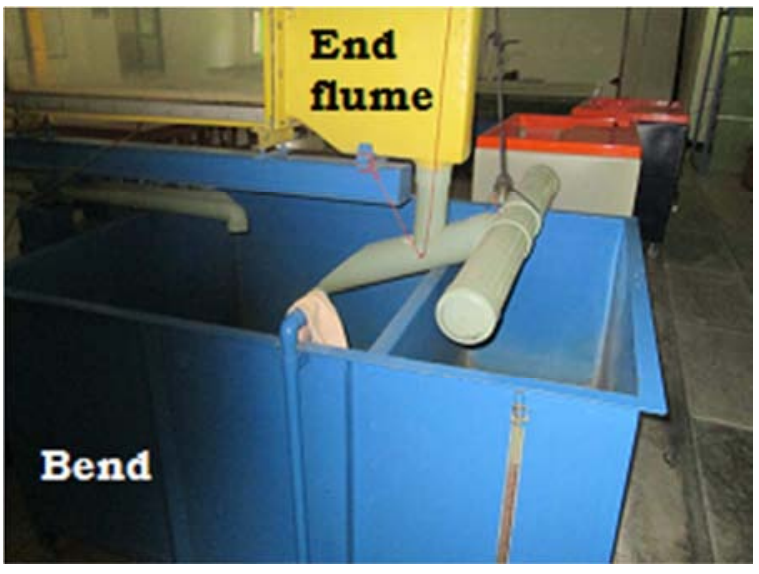

Figure 5. Bend for discharge measurement.

Longitudinal flow depths are measured using a rail mounted pointer gauge positioned over the channel (Figure 4). During the experiments, the location of the hydraulic jump was controlled by the downstream gate. For one discharge value, the hydraulic jump parameters were measured for 4 times. 


\section{Hydraulic Jump Parameters Measurement}

The three parameters of the hydraulic jump which were measured are upstream depth $\left(h_{1}\right)$ and downstream depth $\left(\mathrm{h}_{2}\right)$ and length $\left(L_{\mathrm{j}}\right)$ of hydraulic jump. The measurement result can be seen in Table 1, 2, 3, 4, and 5. Table 5 is correlation of hydraulic jump depth and length.

Table 1. Result of hydraulic jump parameter measurement with discharge 1.072 liter/second and high of gate open is $1.0 \mathrm{~cm}$.

\begin{tabular}{|c|c|c|c|c|c|}
\hline \multirow{2}{*}{ Q (liter/s) } & \multirow{2}{*}{ High of gate open (cm) } & \multirow{2}{*}{ Measurement number } & \multicolumn{2}{|l|}{ Depth } & \multirow{2}{*}{$\begin{array}{l}\text { Length of Hydraulic jump Lj } \\
\text { (cm) }\end{array}$} \\
\hline & & & Upstream h1 (cm) & Downstream h2 (cm) & \\
\hline \multirow[t]{4}{*}{1.072} & 1.0 & 1 & 0.8 & 6.6 & 32.3 \\
\hline & & 2 & 1.0 & 6.7 & 41.6 \\
\hline & & 3 & 1.2 & 5.7 & 34.8 \\
\hline & & 4 & 1.4 & 5.6 & 30.4 \\
\hline
\end{tabular}

Table 2. Result of hydraulic jump parameter measurement with discharge 1.072 liter/second and high of gate open is $1.3 \mathrm{~cm}$.

\begin{tabular}{|c|c|c|c|c|c|}
\hline \multirow{2}{*}{$\mathbf{Q}$ (liter/s) } & \multirow{2}{*}{ High of gate open (cm) } & \multirow{2}{*}{ Measurement number } & \multicolumn{2}{|l|}{ Depth } & \multirow{2}{*}{$\begin{array}{l}\text { Length of Hydraulic jump } \mathrm{Lj} \\
\text { (cm) }\end{array}$} \\
\hline & & & Upstream h1 (cm) & Downstream h2 (cm) & \\
\hline \multirow{4}{*}{1.072} & 1.3 & 1 & 1.2 & 6.4 & 26.4 \\
\hline & & 2 & 1.3 & 5.1 & 22.4 \\
\hline & & 3 & 1.7 & 4.3 & 17.5 \\
\hline & & 4 & 1.8 & 3.9 & 12.8 \\
\hline
\end{tabular}

Table 3. Result of hydraulic jump parameter measurement with discharge 1.387 liter/second and high of gate open is $1.0 \mathrm{~cm}$.

\begin{tabular}{|c|c|c|c|c|c|}
\hline \multirow{2}{*}{ Q (liter/s) } & \multirow{2}{*}{ High of gate open $(\mathrm{cm})$} & \multirow{2}{*}{ Measurement number } & \multicolumn{2}{|l|}{ Depth } & \multirow{2}{*}{$\begin{array}{l}\text { Length of Hydraulic jump Lj } \\
\text { (cm) }\end{array}$} \\
\hline & & & Upstream h1 (cm) & Downstream h2 (cm) & \\
\hline \multirow[t]{4}{*}{1.387} & 1.0 & 1 & 0.9 & 8.1 & 43.7 \\
\hline & & 2 & 1.0 & 7.8 & 41.3 \\
\hline & & 3 & 1.2 & 7.1 & 36.2 \\
\hline & & 4 & 1.2 & 6.8 & 34.6 \\
\hline
\end{tabular}

Table 4. Result of hydraulic jump parameter measurement with discharge 1.387 liter $/$ second and high of gate open is $1.3 \mathrm{~cm}$.

\begin{tabular}{|c|c|c|c|c|c|}
\hline \multirow{2}{*}{ Q (liter/s) } & \multirow{2}{*}{ High of gate open $(\mathrm{cm})$} & \multirow{2}{*}{ Measurement number } & \multicolumn{2}{|l|}{ Depth } & \multirow{2}{*}{$\begin{array}{l}\text { Length of Hydraulic jump } \mathrm{Lj} \\
\text { (cm) }\end{array}$} \\
\hline & & & Upstream h1 (cm) & Downstream h2 (cm) & \\
\hline \multirow[t]{4}{*}{1.387} & 1.3 & 1 & 1.1 & 7.10 & 40.8 \\
\hline & & 2 & 1.2 & 7.15 & 38.8 \\
\hline & & 3 & 1.3 & 6.10 & 31.2 \\
\hline & & 4 & 1.4 & 5.90 & 30.0 \\
\hline
\end{tabular}

Table 5. Correlation of hydraulic jump depth and length.

\begin{tabular}{lll}
\hline Hydraulic jump depth & & $\begin{array}{l}\text { Hydraulic jump } \\
\text { length } \mathbf{L j}(\mathbf{c m})\end{array}$ \\
\hline Upstream h1 (cm) & Downstream h2 $(\mathbf{c m})$ & 32.3 \\
0.8 & 6.60 & 41.6 \\
1.0 & 6.10 & 34.8 \\
1.2 & 5.70 & 30.4 \\
1.4 & 5.60 & 26.4 \\
1.2 & 6.40 & 22.4 \\
1.3 & 5.10 & 17.5 \\
1.7 & 4.30 & 12.8 \\
1.8 & 3.90 & 43.7 \\
0.9 & 8.10 & 41.3 \\
1.0 & 7.80 & 35.2 \\
1.2 & 7.10 & 34.6 \\
1.2 & 6.80 & 40.8 \\
1.1 & 7.10 & 38.8 \\
1.2 & 7.15 & 31.2 \\
1.3 & 6.10 & 30.0 \\
1.4 & 5.90 &
\end{tabular}

Table 6. Correlation of hydraulic jump coefficient and length.

\begin{tabular}{llll}
\hline No. & $\begin{array}{l}\text { Difference of } \\
\text { h2 and } \mathbf{~} \mathbf{1}(\mathbf{c m})\end{array}$ & $\begin{array}{l}\text { Hydraulic jump } \\
\text { length } \mathbf{L j} \mathbf{( c m})\end{array}$ & $\begin{array}{l}\text { Hydraulic jump length } \\
\text { coefficient } \mathbf{C} \mathbf{j}=\mathbf{L j} / \mathbf{( h 2}-\mathbf{h} \mathbf{)})\end{array}$ \\
\hline 1 & 5.80 & 32.3 & 5.569 \\
2 & 5.10 & 41.6 & 8.157 \\
3 & 4.50 & 34.8 & 7.733 \\
4 & 4.20 & 30.4 & 7.238 \\
5 & 5.20 & 26.4 & 5.077 \\
6 & 3.80 & 22.4 & 5.895 \\
7 & 2.60 & 17.5 & 6.731 \\
8 & 2.10 & 12.8 & 6.095 \\
9 & 7.20 & 43.7 & 6.069 \\
10 & 6.80 & 41.3 & 6.074 \\
11 & 5.90 & 35.2 & 5.966 \\
12 & 5.60 & 34.6 & 6.179 \\
13 & 6.00 & 40.8 & 6.800 \\
14 & 5.95 & 38.8 & 6.521 \\
15 & 4.80 & 31.2 & 6.500 \\
16 & 4.50 & 30.0 & 6.667 \\
\hline \multirow{2}{*}{ Average of hydraulic jump length coefficient $\left(C_{\mathrm{j}}\right)$ is 6.454.}
\end{tabular}




\section{Data Analysis and Results}

As mentioned in above paragraphs that the hydraulic jump length coefficient functions which desired are such as in equation (11) and (12). In those equations $C_{\mathrm{j}}$ is a function of $\mathrm{h}_{1} / \mathrm{h}_{2}$ ratio, therefore to find the coefficient and power of the both equations are required regression analysis. The data for the analysis is in Table 7 which derived from Table 5.

Table 7. Correlation of $h_{1} / h_{2}$ and $C_{j}$.

\begin{tabular}{lll}
\hline No. & $\mathbf{h}_{\mathbf{1}} / \mathbf{h}_{\mathbf{2}}$ & $\boldsymbol{C}_{\mathbf{j}}$ \\
\hline 1 & 0.1212 & 5.569 \\
2 & 0.1639 & 8.157 \\
3 & 0.2105 & 7.733 \\
4 & 0.2500 & 7.238 \\
5 & 0.1875 & 5.077 \\
6 & 0.2549 & 5.895 \\
7 & 0.3953 & 6.731 \\
8 & 0.4615 & 6.095 \\
9 & 0.1111 & 6.069 \\
10 & 0.1282 & 6.074 \\
11 & 0.1690 & 5.966 \\
12 & 0.1765 & 6.179 \\
13 & 0.1549 & 6.800 \\
14 & 0.1678 & 6.521 \\
15 & 0.2131 & 6.500 \\
16 & 0.2373 & 6.667 \\
\hline
\end{tabular}

Results of regression process in linear form are Equation (17) and in Figure 6.

$$
C_{\mathrm{j}}=6.3273+0.5974\left(h_{1} / h_{2}\right)
$$

With correlation coefficient, $r=0.073$

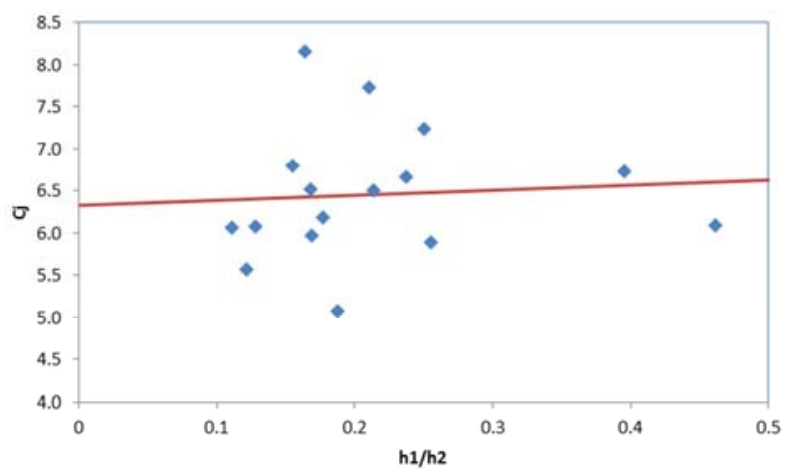

Figure 6. Relation of $C_{j}$ and $h_{1} / h_{2}$ in linear form.

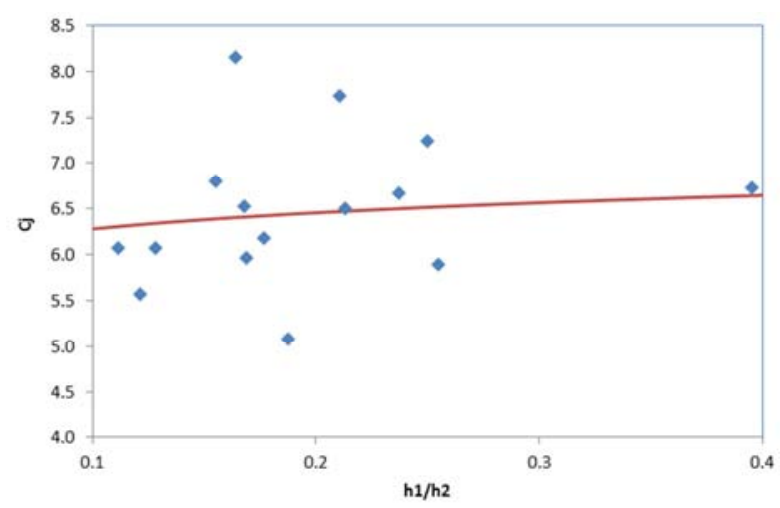

Figure 7. Relation of $C_{j}$ and $h_{1} / h_{2}$ in power form.
Results of regression process in power form are Equation (18) and in Figure 7.

$$
C_{\mathrm{j}}=3.8274+3.0883\left(h_{1} / h_{2}\right)^{0.1}
$$

With correlation coefficient, $\mathrm{r}=0.133$

Power of 0.1 in equation (18) was adjusted to obtain the optimum $r$, i.e. $r=0.133$.

\section{Discussion}

Based on the literature review which mention above that researchers such as Bakhmeteff and Matzke, Smetana, Kinney, Riegel and Beeba, Aravin, Triatmojo, Wu, Woycicki, Ivanchenko have used Equation (7) to compute the length of hydraulic jump. Each of the researches gave the $C_{\mathrm{j}}$ quantity that different beetwen a researcher to another according to Equation (7).

\section{1. $C_{j}$ with Specific Quantity}

Bakhmeteff and Matzke, Smetana, Kinney, Riegel and Beeba, Aravin gave a fixed value of $C_{\mathrm{j}}$ i.e. 5.0, 6.0, 6.2, 5.0, 5.4 respectively and Triatmojo gave the $C_{\mathrm{j}}$ value in range from 5 to 7. Based on experiments in laboratory in this study was found range of the $C_{\mathrm{j}}$ from 5.569 to 8.157 . The range is greater than $C_{\mathrm{j}}$ value which given by researchers before i.e. 5 to 7 . From the experiment the average value of $C_{\mathrm{j}}=6.454$. The value bigger than $C_{\mathrm{j}}$ which were given by all researchers above and the closer value of $C_{\mathrm{j}}=6.454$ is from Kinney with $C_{\mathrm{j}}=6.2$.

\section{2. $C_{j}$ in the Linear Function Form}

In this study the independent variable of $C_{\mathrm{j}}$ function was ratio of $h_{1} / h_{2}$, different from was given by other researchers which use ratio of $h_{2} / h_{1}$ or $F r_{1} . F r_{1}$ is a Froude number in upstream of hydraulic jump with depth $h_{1}$. The result of the study in linear function (see Equation 17) is,

$$
C_{\mathrm{j}}=6.3273+0.5974\left(h_{1} / h_{2}\right)
$$

From Woicicki, the equation is.

$$
C_{\mathrm{j}}=8.0-0.05\left(h_{2} / h_{1}\right)
$$

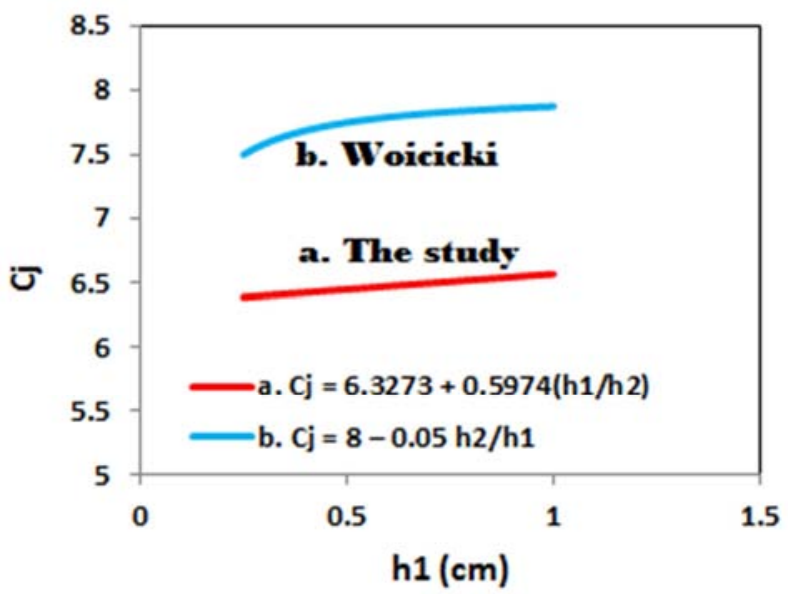

Figure 8. Correlation of $C_{j}$ and $h_{l}$. 


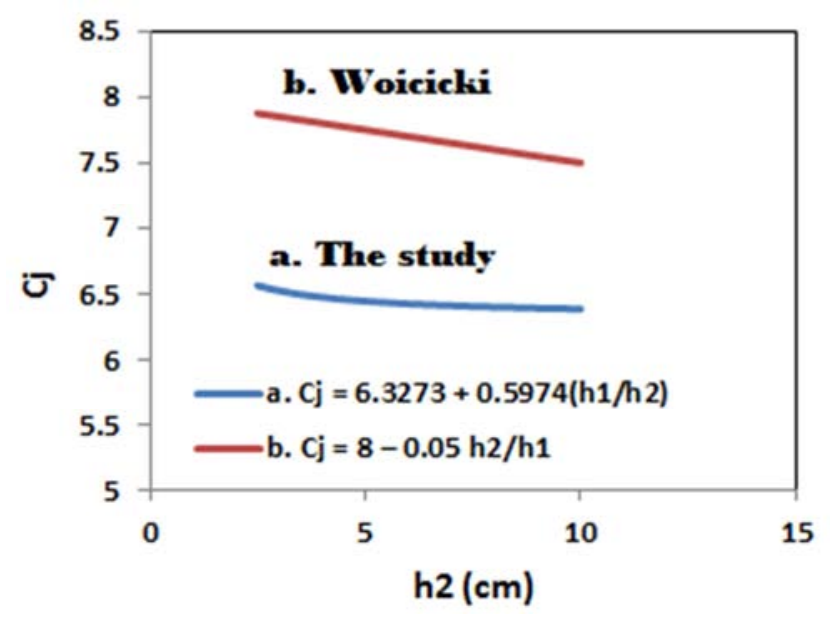

Figure 9. Correlation of $C_{j}$ and $h_{2}$.

Comparison of Equation (19) to (20) can be seen in Figure 8 and 9.

Figure 8 show that correlation between $C_{\mathrm{j}}$ and $h_{1}$ give straight line trench for Woicicki formula and arch line for the result of the study and Figure 9 show that correlation between $C_{\mathrm{j}}$ and $h_{2}$ give straight line trench for the result of the study and arch line for Woicicki formula.

Based on Figure 8 and 9 in general calculation result of $C_{\mathrm{j}}$ with Woicicki formula is greater than the study formula.

\section{3. $C_{j}$ in Power Form}

The result of the study in power function (see Equation 18) is,

$$
C_{\mathrm{j}}=3.8274+3.0883\left(h_{1} / h_{2}\right)^{0.1}
$$

The Equation from $\mathrm{Wu}$ and Ivanchenko are in Equation (22) and (23) respectively.

$$
\begin{aligned}
& C_{\mathrm{j}}=10.0 F r_{1}^{-0.16} \\
& C_{\mathrm{j}}=10.6 F r_{1}^{-0.185}
\end{aligned}
$$

Comparison of Equation (21) to (22) adn (23) can be noticed in Figure 10.

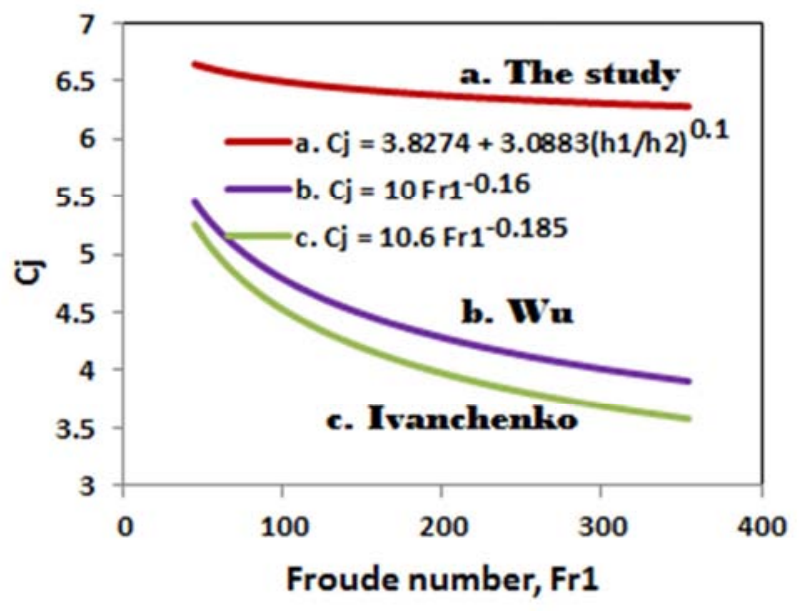

Figure 10. Correlation of $C_{j}$ and $\mathrm{Fr}_{I}$
Based on Figure 10, in general computation result of $C_{\mathrm{j}}$ with $\mathrm{Wu}$ or Ivanchenko formula is smaller than the study formula.

\section{Conclusion}

The coefficient of hydraulic jump length $\left(C_{\mathrm{j}}\right)$ associated with Equation (7) has been gained in form of fixed value, linear function, and power function with independent variable was ratio of $h_{1} / h_{2}$.

The average value (fixed value) of hydraulic jump length coefficient from the experiment was $C_{\mathrm{j}}=6.454$. The value bigger than which were provided by researchers before. The closer value to the $C_{\mathrm{j}}=6.454$ was given by Kinney (1935) with value $C_{\mathrm{j}}=6.2$. The fixed value of $C_{\mathrm{j}}=6.454$ can be used in practical purpose because the value close to Kenney $C_{\mathrm{j}}=6.2$ and in the range of 5 to 7 propose by Triatmojo (1993).

In the study independent variable that was utilized associated with Equation (7) is a ratio of $h_{1} / h_{2}$. A function which can be obtained from regression analysis in linear form was $C_{\mathrm{j}}=6.3273+0.5974\left(h_{1} / h_{2}\right)$. The function is different from Woicicki formula which used variable $h_{2} / h_{1}$, Equation (20). In power form the function is $C_{\mathrm{j}}=3.8274+$ $3.0883\left(h_{1} / h_{2}\right)^{0.1}$. Wu and Ivanchenko gave formula in variable of Froude number $\left(F r_{1}\right)$ i.e. $C_{\mathrm{j}}=10 F r_{1}^{-0.16}$ and $C_{\mathrm{j}}=10.6 F r_{1}{ }^{-}$ 0.185 respectively. Wu and Ivanchenko formula gave smaller value than the value of the study equation.

The two functions can be utilized in practical purpose to calculate $C_{\mathrm{j}}$ coefficient to determine the length of hydraulic jump because the $C_{\mathrm{j}}$ value from the function within the range of 5 to 7 (Triatmojo 1993).

In general hydraulic jump length coefficient was found from the study appropriate to be applied to calculate the hydraulic jump length to design a stilling basin in downstream of the weir.

\section{Recommendation}

The research gives the result no satisfied based on discussions and conclusions above. Although such the other research needed to acquire the hydraulic jump length coefficient that more accurate.

\section{References}

[1] Alikhani, A., Behrozi-Rad, R., and Fathi-Moghadam, M., (2010). Hydraulic jump in stilling basin with vertical end sill, International Journal of Physical Sciences Vol. 5 (1), pp. 025029.

[2] Aravin, 1935 in Thandaveswara, (2017). Hydraulics Course Material, Section 29.5. Acceced January, 8, 2017 from nptel.ac.in/courses/105106114/pdfs/Unit29/29_5.pdf.

[3] Bakhmeteff dan Matzke, 1936 in Thandaveswara, (2017). Hydraulics Course Material, Section 29.5. Acceced January, 8, 2017 from ptel.ac.in/courses/105106114/ pdfs/Unit29/29_5.pdf. 
[4] Chanson, H., and Montes, J. S. (1995). "Characteristics of Undular Hydraulic Jumps. Experimental Apparatus and Flow Patterns." Journal of Hydraulic Engineering, ASCE, Vol. 121, No. 2, pp. 129-144.

[5] Chanson, H. (1996). "Hydraulic Characteristics of Undular Hydraulic Jumps. Experimental Apparatus and Flow Patterns." Journal of the Chinese Institute of Civil and Hydraulic Engineering, Vol. 8, No. 3, pp. 477-482.

[6] Chertoussov, 1935 in Thandaveswara, (2017). Hydraulics Course Material, Section 29.5. Acceced January, 8, 2017 from nptel.ac.in/ courses/ 105106114/pdfs/Unit29/29_5.pdf.

[7] Douma, 1934 in Thandaveswara, (2017). Hydraulics Course Material, Section 29.5. Acceced January, 8, 2017 from nptel.ac.in/courses/105106114/pdfs/Unit29/29_5.pdf.

[8] Ivanchenko, 1935 in Thandaveswara, (2017). Hydraulics Course Material, Section 29.5. Acceced January, 8, 2017 from nptel.ac.in/ courses/105106114/pdfs/Unit29/29_5.pdf.

[9] Kinney, 1935 in Thandaveswara, (2017). Hydraulics Course Material, Section 29.5. Acceced January, 8, 2017 from nptel.ac.in/courses/105106114/pdfs/Unit29/29_5.pdf.

[10] Ludin, 1927 in Thandaveswara, (2017). Hydraulics Course Material, Section 29.5. Acceced January, 8, 2017 from nptel.ac.in/courses/105106114/pdfs/Unit29/29_5.pdf.

[11] Page, 1935 in Thandaveswara, (2017). Hydraulics Course Material, Section 29.5. Acceced January, 8, 2017 from
nptel.ac.in/courses/105106114/pdfs/Unit29/29 5.pdf.

[12] Posey, 1941 in Thandaveswara, (2017). Hydraulics Course Material, Section 29.5. Acceced January, 8, 2017 from nptel.ac.in/courses/105106114/pdfs/Unit29/29_5.pdf.

[13] Riegel dan Beeba, 1917 in Thandaveswara, (2017). Hydraulics Course Material, Section 29.5. Acceced January, 8, 2017 from nptel.ac.in/ courses/ 105106114/ pdfs/Unit29/29_5.pdf.

[14] Safranez, 1933-39 in Thandaveswara, (2017). Hydraulics Course Material, Section 29.5. Acceced January, 8, 2017 from nptel.ac.in/ courses/105106114/pdfs/Unit29/29_5.pdf.

[15] Smetana, ( ) in Thandaveswara, (2017). Hydraulics Course Material, Section 29.5. Acceced January, 8, 2017 from nptel.ac.in/courses/105106114/pdfs/Unit29/29 5.pdf.

[16] Triatmojo B. (1993). Hidraulika II, Penerbit Beta Offset Yogyakarta.

[17] Wu, 1949 in Thandaveswara, (2017). Hydraulics Course Material, Section 29.5. Acceced January, 8, 2017 from nptel.ac.in/courses/105106114/pdfs/Unit29/29_5.pdf.

[18] Woycicki, 1931 in Thandaveswara, (2017). Hydraulics Course Material, Section 29.5. Acceced January, 8, 2017 from nptel.ac.in/courses/105106114/pdfs/Unit29/29_5.pdf. 